\title{
THE ROLE OF COST MANAGEMENT STRATEGIES FOR SME BUSINESS: A CONCEPTUAL FRAMEWORK
}

\author{
Zahirul Alam Kajal \\ Graduate Student \\ School of Economics and Management \\ Chongqing Jiaotong University, P.R. China \\ E-mail: 622202130001@ mails.cqjtu.edu.cn \\ Mukut Sikder \\ PhD Student \\ School of Economics and Management \\ Chang'an University, China \\ E-mail: mukutsikder@chd.edu.cn \\ Ashamoni \\ Graduate Student \\ Department of Arts \\ Bogra Govt. Mujibur Rahman Mohila College \\ National University, Bangladesh \\ E-mail: tanishatasnimanu@yahoo.com \\ Paruss Panhwar \\ Graduate Student \\ Department of Law and Public administration \\ China Three Gorges University, China \\ E-mail: panhwarparuss05@gmail.com
}

\begin{abstract}
The main purpose of this research is to concern analytic knowledge of the role of cost management strategies for SMEs business and create financial sustainability. SME enterprises are playing a key role in creating entrepreneurship and eliminating unemployment in every country by raising capital through various means. In this case, the expected triumph will not come unless there is a proper concept on cost management. The effectiveness of Cost Management policy for perspective Planning in the finance with a point of next and accelerate growth in SMEs business. The authors have been used a conceptual model and employed secondary data, and developed hypotheses based on the significance of research objectives. The theoretical analysis carries out the standard cost management strategies with advantages and disadvantages, and financial management is providing remarkable knowledge to SME organizations and entrepreneurs as well as emphasized for creating specific strategies based on business. The article has been conducted current theoretical knowledge, and only analyzes the accomplishment of management policies on the enhancement of SMEs business field that limits
\end{abstract}


the scope of the research quarry. This research contributes to the potential knowledge and delivers an applicable conceptual framework for the $21^{\text {st }}$ century of the various small and medium business sectors.

Keywords: Cost management, SMEs business, 21st century, ADB, OECD.

JEL Classification Codes: M31, B20, M39.

\section{INTRODUCTION}

Small and medium businesses are the economic driving force of a country and play a significant role of a country in reducing unemployment, increasing domestic production, and contributing to increasing GDP growth, contributing to developmental work by giving tax to the government, socio-economic development, and so on. Depending on the organization's staff, Employees, size of the investment, and assets, these organizations are divided into different countries around the world.

Furthermore, SMEs are the prominent vehicle for economic growth and employment creation in every country, and epitomize $90 \%$ of the world's businesses and provide over $50 \%$ of the world's total employment. In addition, developed and developing countries manage an average of $40 \%$ of GDP by microfinance business (WorldBank, 2021).Currently, the SMEs sector is not improving in many countries due to raising the prices of raw materials, lack of skilled manpower, and other facilities. In this consequence, cost management may create a significant contribution to the improvement of SMEs. This study aims to research how the effective framework and policy of cost management will be acceptable to the 21st century and may carry SME's business activity-based planning and strategic management in the future. In this context, we emphasized the global investigation of the appreciation of financial improvement cost management policy and wanted to highlight the features and parts of these ideas in the modern era attributed by the alternative in the business field. This concept likes to be crucially applicable; we consider, modern cost management strategy will follow this framework in its future SME's business and finance development.

At present times, all types of business management policies are possible to variation dramatically. Specifically, the enterprises are extraordinarily forced to trace workable strategies to enhance their competitive position, and financial performance as well as the value of their partners. In addition, with the intense competition and challenges to be faced businesses are asked to place more emphasis on using potential strategic decisions. Furthermore, the desired initiative to create a business of any size (Small, Medium, and Large) is appropriate and selfsufficient in current times (Voronkova et al., 2019). The business proprietors are separated who realize, introduce, and accept challenges for new financial operations as a business venture. It has been noticed that small and medium businesses are as old as the barter and trade traditionally (Akbar et al., 2011).In this consideration, Cost management vitally supports proprietors to create affordable businesses and safe capital. This quality of efforts delivers in large part on improving the natural life in the society and giving an attractive microfinance business market. Currently, there is worldwide competition between business and productive resources to find a more favorable place to achieve their primary goals (Rocha de Araujo \& Pacheco da Costa, 2005). In other words, the factors include business product quality maintain, optimal delivery time, innovation policy, and cost savings (Savić et al., 2014). Despite cost management are not only one of the key factors, but also paramount of significance. Moreover, cost management is a framework for marketplace cost data into decision-making in assist of business's strategic plan as 
well as demarking as a decision about a certain cost operator. In the theory of a company's business policy and its area in the long-term value chain extending from asset improvement.

Therefore, this study examines deeply strategic cost management plays a major role as a competitive element for SME's business continued existence in this century. So, starting any category of business cost management must be considered as one of the multiplier elements to develop its sufficiency. In general, the problem in SMEs is that most of the stakeholders being business arrange a certain amount of capital, and take short ventures without proper preparation or exact knowledge (Wall et al., 2011). The issue with particular businesses is that most of the entrepreneurs lack efficiency and cost management knowledge strategically handles to get profit in business over a long period of time. The main purpose of this study there are few particular objectives as follows;

a) To emphasize the potential strategy for cost management in SMEs business

b) To examine the relationship between business management and microfinance

c) To provide analytic global knowledge which specific factors have to concentrate for SMEs growth in $21^{\text {st }}$ century

Therefore, this study analyzed business performance in cost management policy, management of SMEs, and it represents a global conceptual scenario that overall contributes to building a sustainable business. Then we developed an analytical discussion based on results and an overview of the global scenario which shows that each of the category's business performance levels. Subsequently, it contributes to SME businesses firm to formulate their appropriate strategies. At last, we have suggested the policy implications with concluding remarks.

\section{A CONCEPTUAL FRAMEWORK}

The role of cost management is considered in several points of view in literature. Cost management is the proper application of business cost management methods at one time develop the policy condition of a business and decline wasteful expenses. Cost management is related to the process of discovering the exact way and directing the business in the fruitful pathway.

In addition, cost management greatly helps to provide an effective idea about the whole procedure of budget framing and monitoring of the business. Having a remarkable cost management plan helps financial institutions to encourage any category of business or organization to implement the business and share the knowledge about appropriate policies to get financial support. Moreover, a policy that allows a SMEs business to forecast further expenses to assist decrease the likelihood of running overfunds. Most businesses use cost management strategies for the over-all-business model to implement a particular business. Besides, when establishing it to a business or project, the prospective value is counted while the business is in the plan and has been approved in advance. Being the business, all expenditure is listed and addressed so that they are consistent with the cost management plan after the business is started. Later, predicted expenditure and real cost may be balanced and analyzed, cooperating to predict the next cost management and budget. 




Figure 1. Four main steps of an effective business cost management Source: Author's created

Subsequently, cost management is a comprehensive segment that includes various data collection, analysis, and monitoring performances. To be a profitable entrepreneur or businessman in the long run, have to spend valuable time concentrating on each of these cost management operations.

\section{The global concept of SME}

Generally, every country has an individual SME definition based on specific business policies. Table 1showthat the definition of SMEs in South Asia has observed many factors. Most of these, the lowest and highest number of employees, total assets, capital, annual revenue, and annual sales of the organization.

Table 1. SME's Scenario and definition of South and Southeast Asia

\begin{tabular}{|c|c|c|c|c|}
\hline Items & Bangladesh & India & Malaysia & Indonesia \\
\hline $\begin{array}{l}\text { Size of } \\
\text { Investment/Assets/ } \\
\text { Turnover/Annual }\end{array}$ & $\begin{array}{l}\text { Small Size: } \\
\text { Manufacturing } \\
\text { sector; Assets Tk } \\
50 \text { thousand to Tk } \\
1.5 \text { crore. } \\
\text { Service and } \\
\text { business sector; } \\
\text { Assets Tk 50 } \\
\text { thousand to Tk } 5 \\
\text { lakh. } \\
\text { Medium Size: }\end{array}$ & $\begin{array}{l}\text { Micro Size: } \\
\text { Manufacturing } \\
\text { sector; Capital } \\
\text { fewer than Rs } 2.5 \\
\text { Million. } \\
\text { Service sector; } \\
\text { Capital fewer than } \\
\text { Rs 1 Million. } \\
\text { Small Size: } \\
\text { Manufacturing } \\
\text { Sector; CapitalRs }\end{array}$ & $\begin{array}{l}\text { Micro Size: } \\
\text { Manufacturing, } \\
\text { Service\& others } \\
\text { sector; Turnover fewer } \\
\text { than RM } 3 \text { lakh. } \\
\text { Small Size: } \\
\text { Manufacturing sector; } \\
\text { Turnover RM3 lakh to } \\
\text { RM15 Million. } \\
\text { Service \&another } \\
\text { sector; TurnoverRM3 }\end{array}$ & $\begin{array}{l}\text { Micro Size: } \\
\text { Assets less } \\
\text { than RP50 } \\
\text { Million. } \\
\text { Small Size: } \\
\text { AssetsRP50 } \\
\text { Million } \\
\text { toRp500 } \\
\text { Million. } \\
\text { Medium } \\
\text { Size: }\end{array}$ \\
\hline
\end{tabular}




\begin{tabular}{|c|c|c|c|c|}
\hline Sales & $\begin{array}{l}\text { Manufacturing } \\
\text { sector; Assets Tk } \\
1.5 \text { crore to Tk } 20 \\
\text { crore. } \\
\text { Service and } \\
\text { business sector; } \\
\text { Assets } 50 \text { lakh to } \\
\text { Tk } 10 \text { crore. }\end{array}$ & $\begin{array}{l}\text { 2.5 Million to Rs } \\
50 \text { Million. } \\
\text { Service } \\
\text { sector;CapitalRs } 1 \\
\text { Million to Rs } 20 \\
\text { Million. } \\
\text { Medium Size: } \\
\text { Manufacturing } \\
\text { Sector; Capital Rs } \\
\text { 50 Million to Rs } \\
100 \text { Million. } \\
\text { Service sector; } \\
\text { Capital Rs } 20 \\
\text { Million to Rs } 50 \\
\text { Million. }\end{array}$ & $\begin{array}{l}\text { lakh to RM3 Million. } \\
\text { Medium Size: } \\
\text { Manufacturing } \\
\text { sector;Turnover RM15 } \\
\text { MilliontoRM50 } \\
\text { Million. } \\
\text { Service \& } \\
\text { anothersector; } \\
\text { TurnoverRM20 } \\
\text { Million. }\end{array}$ & $\begin{array}{l}\text { Assets RP500 } \\
\text { Millionto } \\
\text { RP10 Billion. }\end{array}$ \\
\hline $\begin{array}{l}\text { Employed of the } \\
\text { workforce }\end{array}$ & $70-80 \%$ & $79.9 \%$ & $66.2 \%$ & $97 \%$ \\
\hline $\begin{array}{l}\text { Contribution to } \\
\text { GDP }\end{array}$ & $25 \%$ & $37.5 \%$ & $38.3 \%$ & $61 \%$ \\
\hline Defined By & $\begin{array}{l}\text { Assets, Number of } \\
\text { Employees }\end{array}$ & Capital & $\begin{array}{l}\text { Number of } \\
\text { Employees, Turnover }\end{array}$ & $\begin{array}{l}\text { Assets, } \\
\text { Turnover }\end{array}$ \\
\hline
\end{tabular}

Source: Bangladesh Bank and Asian Development Bank

In Bangladesh, if the total assets of the manufacturing companies excluding land and factories are between Tk 50,000 to Tk 1.5 crore, it is considered a small enterprise, and if the amount of the assets between Tk 1.5 crore to Tk 20 crore, it is defined as a medium enterprise. In the case of service providers, those with assets excluding land and factories Tk 50,000 to Tk 50 lakh are considered small, and those with assets of Tk 50 lakh to Tk 10 crore are considered as medium enterprises. In other words, if it has 20-50 employees, it is measured as a small organization and if it has 50-150 employees, it is defined as a medium organization(Bangladesh Bank, 2010). SMEs contribute $70-80 \%$ to the nonagricultural workforce, and $25 \%$ to the GDP of Bangladesh stated by ADB (2014).

In India, if an organization with less than 100 employees is considered a microenterprise, over 100 employees are small and an organization with 100 to 499 employees is considered as a medium enterprise. Also, in the case of manufacturing companies, if the capital is less than Rs 2.5 million, it is considered micro, if it is Rs 2.5 million to Rs 50 million, it is small, if it is Rs 50 million to Rs 100 million, it is considered as a medium enterprise. In the case of service providers, if the capital is less than Rs 1 million, it is considered as micro, if it is Rs 1 million to Rs 20 million, it is considered as small, and if it is Rs 20 million to Rs 50 million, it is considered as medium service providers (ADB, 2016). SMEs contribute 37.5\% to India's GDP and $79.9 \%$ to employment reported by $\operatorname{ADB}(2017)$.

In Malaysia, in the case of manufacturing companies, if the annual sales turnover is fewer than Rm 3 lakh with 5 employees, it is a micro-enterprise. If it is between Rm 3 lakh to Rm 15 million with 5-74 employees, it is considered as a small company and if it is between Rm 15 million to Rm 50 million with 75-200 employees, it is considered as a medium enterprise. In the case of service providers, if the annual sales turnover is $\mathrm{Rm} 3$ lakhs to $\mathrm{Rm} 3$ million with 5-29 
employees, it is measured as a small company, if it is $\mathrm{Rm} 3$ million to $\mathrm{Rm} 50$ million with 30-75, it is defined as a medium company. SMEs contribute $38.3 \%$ to Malaysia's GDP and $66.2 \%$ to employment concluded by Asian Development Bank (2020).

In Indonesia, excluding land building, if the net worth is less than $\mathrm{Rp} 50$ million, it is considered micro-enterprise, if it is Rp 50 million to $\mathrm{Rp} 500$ million, it is small and if it is $\mathrm{Rp} 500$ million to $\mathrm{Rp} 10$ billion, it is considered as a medium enterprise. SMEs contribute 97\% of Indonesia's national employment and 61\% of GDP(Asian Development Bank, 2020).

There are many variances in the definition of SME in Central and Central Asia. In China a total of 15 sectors were classified as SMEs by reform in 2003 and 2011. In this case, each sector is defined with a single or dual component. Of these, some are designed by the number of employees, some by the annual income, and some by the number of employees and income combined of an organization. Besides, the total assets and capital of the organization are calculated as SMEs in China (ADB, 2017).In the case of heavy and wholesale industries, if the annual revenue is CYN 400 million and the organization has less than 1000 employees, it is considered as part of SMEs (ADB, 2016).SME's contributions are enormous in China, $60 \%$ to employment and $64.7 \%$ to GDP founded by $\mathrm{ADB}(2016)$.

Table 2. SME's Scenario and definition of Central and East Asia

\begin{tabular}{|c|c|c|c|c|}
\hline Items & Kazakhstan & Tajikistan & China PR & Republic of Korea \\
\hline $\begin{array}{l}\text { Size of } \\
\text { Investment/Assets/ } \\
\text { Turnover/Annual } \\
\text { Sales }\end{array}$ & $\begin{array}{l}\text { Small Size; } \\
\text { Fewer than 50 } \\
\text { Employees with } \\
\text { \$622,000 annual } \\
\text { sales. } \\
\text { Medium Size: } \\
\text { 50-250 Employees } \\
\text { with \$3 Million } \\
\text { annual sales. } \\
\text { SMEs Size: } \\
\text { RevenueKZT5,200 } \\
\text { Million } \\
\text { (\$15.6Million). }\end{array}$ & $\begin{array}{l}\text { Micro } \\
\text { Size: } \\
1-5 \\
\text { Employees. } \\
\text { Small size: } \\
\text { 5-19 } \\
\text { Employees. } \\
\text { Medium } \\
\text { size: } \\
\text { 20-99 } \\
\text { Employees. }\end{array}$ & $\begin{array}{l}\text { SMEs } \\
\text { Size; } \\
\text { Heavy } \\
\text { industry } \\
\text { and } \\
\text { wholesale } \\
\text { industry; } \\
\text { less than } \\
1000 \\
\text { employees } \\
\text { with } \\
\text { Revenue } \\
\text { CNY 400 } \\
\text { Million } \\
\text { (\$61.3 } \\
\text { Million). }\end{array}$ & $\begin{array}{l}\text { SMEs Size: } \\
\text { Manufacturing } \\
\text { sector;AssetsKRW8000 } \\
\text { Million (\$6.9 Million). } \\
\text { Primary/others services } \\
\text { sector;RevenueKRW20,000 } \\
\text { Million (\$17.2 Million). }\end{array}$ \\
\hline $\begin{array}{l}\text { Employed of the } \\
\text { workforce }\end{array}$ & $32.1 \%$ & $35 \%$ & $60 \%$ & $89.9 \%$ \\
\hline $\begin{array}{l}\text { Contribution to } \\
\text { GDP }\end{array}$ & $26 \%$ & $30 \%$ & $64.7 \%$ & $18.8 \%$ \\
\hline Defined By & $\begin{array}{l}\text { Number } \quad \text { of } \\
\text { Employees, } \\
\text { Annual Sales, } \\
\text { Revenue }\end{array}$ & $\begin{array}{l}\text { Number of } \\
\text { Employees, } \\
\text { Turnover }\end{array}$ & $\begin{array}{l}\text { Number of } \\
\text { Employees, } \\
\text { Turnover }\end{array}$ & $\begin{array}{l}\text { Number of Employees, } \\
\text { Turnover, Capital }\end{array}$ \\
\hline
\end{tabular}

Source: Asian Development Bank and OECD 
In Kazakhstan, SMEs are determined based on the organization's specific employees, annual sales and revenue. It is considered a small organization with an annual sale of $\$ 622,000$ withless than 50 employees, and a medium-sized organization with an annual sale of $\$ 3$ million with 50 to 250 employees(ADB, 2017).Also, if the annual revenue of an organization is KZT 5200 million, it is considered as SMEs (ADB, 2016).SMEs make up 26.1\% of Kazakhstan's GDP and $32.1 \%$ of total employment(ADB, 2017).

Tajikistan's SMEs lag far behind other than Central and East Asian countries. The country has many SME sectors. Of these, if the employees of an organization are between 1 to 5, it is considered as a microenterprise and if the employees are between 5 to 19 , it is measured as a small enterprise. If the employees are between 20 to 99 , it is defined as a medium enterprise(OECD, 2015). The role of SMEs in the country's GDP is $30 \%$ and $35 \%$ of the total employment (ADB, 2019).

In the Republic of Korea, SMEs are designated by the number of employees, capital, and turnover of the organization. In the case of manufacturing companies, the amount of assets is KRW 8,000 million and in the case of service providers the revenue is KRW20,000 million of the organization, they are defined as SMEs (ADB, 2016), SMEs account for $18.8 \%$ of Korea's GDP and $89.9 \%$ of employment (ADB, 2017).

Table 3. SME's Scenario and definition of Africa

\begin{tabular}{|c|c|c|c|c|}
\hline Items & Egypt & South Africa & Nigeria & Tanzania \\
\hline $\begin{array}{l}\text { Size of } \\
\text { Investment/Assets } \\
\text { /Turnover/Total } \\
\text { Employees }\end{array}$ & $\begin{array}{l}\text { Micro Size: } \\
\text { More than } 10 \\
\text { Employees } \\
\text { with capital } \\
\text { EGP } 50000 \\
\text { Small Size: } \\
\text { More than 50 } \\
\text { employees with } \\
\text { capital EGP 50 } \\
\text { thousand to } \\
\text { EGP 1 Million. } \\
\text { Medium Size: } \\
\text { Manufacturing } \\
\text { sector; 5-100 } \\
\text { Employees } \\
\text { with capital } \\
\text { EGP 10 } \\
\text { Million. } \\
\text { Service sector; } \\
\text { 10-19 } \\
\text { Employees } \\
\text { with capital } \\
\text { EGP 5 lakh to } \\
\text { EGP } 2 \text { Million. }\end{array}$ & $\begin{array}{l}\text { Micro Size: } \\
\text { Less than } 20 \\
\text { Employees with } \\
\text { turnover R 5lakh. } \\
\text { Small Size: } \\
\text { 21-50 Employees } \\
\text { with turnover R1 } \\
\text { Million in } \\
\text { agriculture, R13 } \\
\text { Million in catering, } \\
\text { R32 Million in } \\
\text { Manufacturing, } \\
\text { Trade, Wholesale. } \\
\text { Medium Size: } \\
\text { Less than 200 } \\
\text { Employees with } \\
\text { turnover R5 } \\
\text { Million in } \\
\text { Agriculture, R51 } \\
\text { million in } \\
\text { Manufacturing, } \\
\text { R64 Million in } \\
\text { trade, wholesale, } \\
\text { service sectors. }\end{array}$ & $\begin{array}{l}\text { Micro Size: } \\
\text { Total Assets N5 } \\
\text { Million with } 10 \\
\text { employees. } \\
\text { Small Size: } \\
\text { Total Assets N5 } \\
\text { Million to N100 } \\
\text { Million with 11- } \\
\text { 50 Employees. } \\
\text { Medium Size: } \\
\text { Total Assets N100 } \\
\text { Million to N500 } \\
\text { Million with 51- } \\
\text { 200 Employees. } \\
\text { SME Size: } \\
\text { 11-300 } \\
\text { Employees with } \\
\text { assets N5 Million } \\
\text { - N500 Million. }\end{array}$ & $\begin{array}{l}\text { Micro Size: } \\
\text { 1-5 Employees } \\
\text { with Tshs 5 } \\
\text { Million } \\
\text { Investment. } \\
\text { Small Size: } \\
\text { 5-59 Employees } \\
\text { with Tshs 5-200 } \\
\text { Million } \\
\text { Investment. } \\
\text { Medium Size: } \\
\text { 50-99 } \\
\text { Employees with } \\
\text { Tshs 200-800 } \\
\text { Million } \\
\text { Investment. }\end{array}$ \\
\hline
\end{tabular}




\begin{tabular}{|l|l|l|l|l|}
\hline $\begin{array}{l}\text { Employed of the } \\
\text { workforce }\end{array}$ & $75 \%$ & $50 \%-60 \%$ & $84 \%$ & $47.4 \%$ \\
\hline $\begin{array}{l}\text { Contribution to } \\
\text { GDP }\end{array}$ & $80 \%$ & $34 \%$ & $50 \%$ & $27 \%$ \\
\hline Defined By & $\begin{array}{l}\text { Capital, } \\
\text { Number of } \\
\text { Employees, } \\
\text { Turnover }\end{array}$ & $\begin{array}{l}\text { Turnover, } \\
\text { Employees }\end{array}$ & $\begin{array}{l}\text { Total Assets, } \\
\text { Number of } \\
\text { Employees }\end{array}$ & $\begin{array}{l}\text { Number Employees } \\
\text { Emplos }\end{array}$ \\
\hline
\end{tabular}

Source: OECD,Central Bank of Nigeria, IFC,and The World Bank

In Egypt, SMEs are defined in many ways as capital, total employees, and turnover. If the capital is EGP 50000, it is defined as a micro-enterprise. If the capital is between EGP 50000 to EGP 1 million, it will be considered as a small enterprise. In the case of medium industrial enterprises, if the capital is 10 million, it is considered as a manufacturing company, and if the capital is betweenEGP5 lakhs to EGP2 million, it is considered as a service organization. The contribution of SMEs to the Egyptian economy is incredible. Involvement in GDP 80\%, and $75 \%$ to employment (OECD, 2010).

In South Africa, SMEs are defined by turnover and a specific number of employees. Micro-enterprise is defined by an R500,000 turnover of an organization. In terms of the definition of small enterprises, between 21 to 50 employees with 1 million turnovers in the agriculture sector, R13 million turnover in the catering sector, R32 million turnover in manufacturing, trade, wholesale industry. In terms of classification of medium enterprises, less than 200 employees with R5 Million turnover in the Agriculture sector, R51 million turnover in the Manufacturing sector, R64 Million turnover in trade, wholesale, service sectors. SMEs contribute to South Africa's GDP is 34\%, and 50\% -60\% to employment (IFC, 2018).

In Nigeria, if the total assets are N5 million with 10 employees, it is considered a microenterprise, if the total assets are N5 million to N100 million with 11 to 50 employees, it is considered a small enterprise, and if the total assets are N100 million to N500 million with 51 to 200 employees, it is considered a medium enterprise. Also, if the total assets are N5 million to N500 million with 11 to 300 employees, it is considered as SMEs (Nigeria, 2010).SMEs contribute 50\% to Nigeria's GDP, and 64\% to employment (PWC, 2020).

In Tanzania, micro-enterprises are defined by a company's capital of Tshs 5 million with 1 to 5 employees. Small enterprises are classified by a company's capital of Tshs 5 million to Tshs 200 million with 5-59 employees, and medium enterprises are designated by a company's capital of Tshs 200 million to Tshs 600 million (TRADE, 2003).SMEs contribute 27\% to Tanzania's GDP and 47.4\% to employment (Sitorus, 2017). 
Table 4. SME's Scenario and definition of North America and Oceania

\begin{tabular}{|c|c|c|c|c|}
\hline Items & Canada & United States & Australia & $\begin{array}{l}\text { New } \\
\text { Zealand }\end{array}$ \\
\hline $\begin{array}{l}\text { Size of Investment } \\
\text { (Assets) } \\
\text { /Turnover/Revenue/Total } \\
\text { Employees }\end{array}$ & $\begin{array}{l}\text { Small Size: } \\
1-99 \\
\text { Employees. } \\
\text { Medium Size: } \\
99-499 \\
\text { Employees. } \\
\text { Large Size: } \\
\text { Over } 500 \\
\text { Employees. }\end{array}$ & $\begin{array}{l}\text { SMEs Size: } \\
\text { Manufacturing \& } \\
\text { Non-exporting } \\
\text { sector; less than } \\
500 \text { Employees. } \\
\text { Exporting Service } \\
\text { sector; less than } \\
500 \text { employees } \\
\text { with revenue \$7- } \\
\text { \$25 Million. } \\
\text { Farm’s sector; less } \\
\text { than 500 } \\
\text { employees with } \\
\text { revenue } \$ 250000 \text {. }\end{array}$ & $\begin{array}{l}\text { Small Size: } \\
\text { Less than } 20 \\
\text { Employees with } \\
\text { turnover } \$ 1-\$ 5 \\
\text { Million. } \\
\text { Medium Size: } \\
\text { 20-199 } \\
\text { Employees with } \\
\text { turnover } \$ 5-\$ 50 \\
\text { Million. }\end{array}$ & $\begin{array}{l}\text { SMEs Size: } \\
\text { Less than } 20 \\
\text { Employees. }\end{array}$ \\
\hline $\begin{array}{l}\text { Employed of the } \\
\text { workforce }\end{array}$ & $61.2 \%$ & $50.2 \%$ & $41 \%$ & $29 \%$ \\
\hline Contribution to GDP & $51.1 \%$ & $50 \%$ & $32 \%$ & $28 \%$ \\
\hline Defined By & $\begin{array}{l}\text { Number } \\
\text { Employees }\end{array}$ & $\begin{array}{l}\text { Number of } \\
\text { Employees, } \\
\text { Revenue }\end{array}$ & $\begin{array}{l}\text { Number of } \\
\text { Employees, } \\
\text { Turnover }\end{array}$ & $\begin{array}{l}\text { Number of } \\
\text { Employees }\end{array}$ \\
\hline
\end{tabular}

Source: International Trade Commission of United States, The Australian Small Business and Family Enterprise Ombudsman, Ministry of Business of New Zealand

SMEs are the main driving force of the economies of North America and Oceania, and a suitable foundation of employment. SMEs have different characteristics and definitions in these areas. In Canada, an organization is considered a small organization if it has 1 to 99 employees and a medium organization with 99 to 499 employees. SMEs contribute $51.1 \%$ to Canada's GDP and $61.2 \%$ to employment (Government of Canada, 2020).

In the United States, SMEs contribute more than 50 percent to job creation and the economy. There are various sectors of SMEs in this country. In the case of SMEs measurement, the number of employees in manufacturing and non-exporting companies, exporting service organizations is less than 500 employees with revenue $\$ 7$ million to $\$ 25$ million, in the firm sector less than 500 employees with revenue $\$ 250000$. The contribution of SMEs to US GDP is $50 \%$, and to employment is $50.2 \%$ (USTDC, 2010).

In Australia, small enterprises are defined by a company's annual turnover of $\$ 1$ million to $\$ 5$ million, and medium enterprises are defined by a company's annual turnover of $\$ 5$ million to $\$ 50$ million. SMEs contribute $32 \%$ to Australia's GDP, and $41 \%$ to employment (FE Ombudsman, 2020). The definition of New Zealand SMEs is demarcated as a company with a certain number of employees. In this case, below 20 employees of all business organizations are considered to be under SMEs, and the SMEs contribute 28\% to New Zealand's GDP, and 29\% to 
employment (Ministry of Business, 2018).

\section{LITERATURE REVIEW AND HYPOTHESIS}

The objective of the present study is to demonstrate the consequential results gained from a number of literature reviews and observations on the vital figure that pay to the attainment of SMEs. Also, this review examines the impact of strategic management on existing contribution organizational performance in the literature. The procedure of observing and analyzing the literature has been used through modern search engines with relevant fields of study in strategic cost management (Fuertes et al., 2020). Moreover, cost and financial management are employed in the discipline of business management creates and delivers empirical knowledge at the foundation, applications, solutions, and applicable context (Malayeri \& Mastorakis, 2012).

\section{Definition of the traditional and strategic cost management}

The prime rule of responsibility for leadership is effective cost management. Cost management involves the accomplishment of effective strategies as well as the giving of resources and system discipline to able and makes sure maximum quality, authenticity, and maximum possible level of productivity at minimum cost (Elliott, 2004).

Traditional cost management until delivers better for financial statement reporting, where it is operated superior over the large units produced for the goals of final pricing. There are no consequences from the consideration of management decision creating.

Table 5. The key features between Traditional and strategic cost management

\begin{tabular}{|l|l|l|}
\hline Key features & Traditional & Strategic \\
\hline Focus & Indigenous & External \\
\hline Main concern & Cost impact & Revenue/Value \\
\hline Perspective & Value added & Value chain \\
\hline Information & Business Contribution oriented & Business Strategy oriented \\
\hline Characteristics & Desperate & Controlled \\
\hline Principal discipline & Finance focused & $\begin{array}{l}\text { Business/Economies } \\
\text { focused }\end{array}$ \\
\hline Outcome & Uncertain & Positive \\
\hline Key role & Point keeper & Consultant \\
Management & Follower & Leader \\
\hline Performance & Short-term win & Long-term win \\
\hline Analysis objective & $\begin{array}{l}\text { Three objectives apply, no } \\
\text { consider to the skillful topic: } \\
\text { point keeping, concern } \\
\text { monitoring, and problem } \\
\text { solving. }\end{array}$ & $\begin{array}{l}\text { Despite the three objectives } \\
\text { are regular modern, the } \\
\text { model of cost management } \\
\text { method different } \\
\text { surprisingly depending on } \\
\text { the general strategic } \\
\text { positioning of the business: } \\
\text { either under a leadership, } \\
\text { product differentiation }\end{array}$ \\
\hline
\end{tabular}




\begin{tabular}{|l|l|l|}
\hline & & strategy. \\
\hline Analysis way & $\begin{array}{l}\text { In term of: consumer, } \\
\text { commodity, and function with a } \\
\text { highly internal Value added are } \\
\text { a main concept. }\end{array}$ & $\begin{array}{l}\text { In terms of: the different } \\
\text { stages of the total value } \\
\text { chain of which the business } \\
\text { is part with a mostly global } \\
\text { focus Value-added is seen } \\
\text { as a risky limited idea. }\end{array}$ \\
\hline
\end{tabular}

Source:(Kumar \& Nagpal, 2011)

In a globally very competitive everywhere, the most financially sustainable business companies see all their expenses as investments. They create innovative costing plans based on their strategic eye and their internal abilities to pay off the investment. Strategic cost management is a method used to develop and monitor business strategies and to manage costs, provide data, and analyze its competitors. Besides, focus on cost lightening and nonstop enrichment, and change rather than just spending. Preliminary strategic studies have been conducted to observe the relationship between strategy, structure, and performance. From a conventional point of view, the production facilities produce numerous, highly non-standard products usually produced in small quantities with labor-intensive processes (Kenyon \& Meixell, 2011). The strategic cost management will improve the SMEs business's condition among competitors and able businesses to identify their strengths and weaknesses (Sulanjaku \& Shingjergji, 2015). Strategic cost management is driven by cost-effectiveness, and if it may increase the competitive chances of new business ventures, then accurately increasing costs is in line with the strategic cost management spirit (Wang, 2019).

The core content of strategic cost management includes all business procedures and responsibilities, besides specific business activities rarely work to decline costs only increase cost efficiency(Michael, 2013).Strategic cost management usually approaches a time of executive classification and handling Strategic reformations policies are located for split businesses for restructuring and those for improvement, including first specified businesses.

\section{Hypothesis: The relationship between strategic and traditional cost.}

\section{Significance of Strategic Financial Management in SMEs}

Many studies have been conducted over the past decade that explores the relationship between strategic planning and company performance in SMEs (Sandada \& Dubihlela, 2017). Financial management is a crucial responsibility of the business owner and must consider the effective outcomes of their management consideration regarding performance, and the financial real situation of the company. Moreover, strategic financial management is duration of familiar discussed the procedure of financial management to perceive the strategic aims of an organization. It is access that conducts several craftsmanship and financial instrument to envision a strategic plan. Strategic financial management confirms that the selected strategy is an accomplishment to gain the intended destinations. 


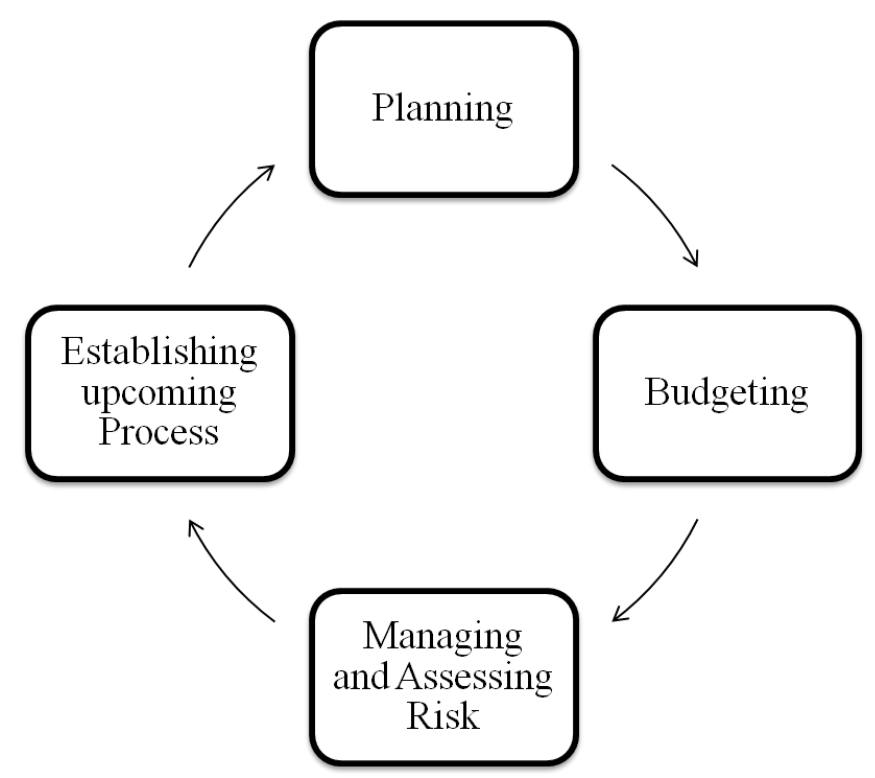

Figure 2. The key components of Strategic Financial Management

Figure 2 indicates that these-primary elements boost to improve effective strategies and oversee action plans compatible with a business purpose and analyze substantial data employing statistical methods with quantitative and qualitative judgment. The importance of strategic financial management is to specify policies that are able to enlarge the market value of the organization (Kaličanin \& Todorović, 2014). Besides, it confirms that the company is effectively obtaining the plan to gain the desired short-term and long-term aims. In fact, defective financial management by the owners-director is the key reason for challenges in SMEs (Jindrichovska, 2013).Microfinance organizations have contributed to the overall economic enhancement depending on the performance of particular companies integrated into the sector (Boohene et al., 2008).

Karadag (2015) argues that the several studies investigated that "the primary reasons for SME business failure are lack of proper financial planning, traditional strategy, and lacks knowledge about cost management, limited funding, and lacks adequate capital, unplanned business cost, excess fixed-asset investment, and capital mismanagement". The concepts of the cost and financial management strategy began to dominate deep research among researchers. However, most of the researches and empirical studies were on the barriers of SMEs, their disability was to force to gain access to finance, and not adequate strong leadership system (Umadia Sr \& Kasztelnik, 2020).

Therefore, financial strategies are defined as a format and accomplishment procedure on activities and financial relationships ( $\mathrm{Li}, 2017)$, which has an important impact on the long-term growth of SMEs.

Hypothesis: The key role between financial management and SME organization.

\section{METHODOLOGY}

The purpose of this paper is to analyze the importance and scope of information support of modern policies in cost managing small and medium enterprises to gain competitive benefit in 
the marketplace.

\section{Data collecting and analysis}

The study has been conducted secondary data from various journal articles, conferences papers, e-books, news portals, yearbooks, and several renowned online databases. The data were analyzed in Microsoft Excel (version 2010) was used to accumulate data, draw the figures and tables. The analyzed data mostly based on the following has been from various previous studies area of management factors, business contributions, and accomplishment policy. The literature studies have been comprehensively relevant to further policies, business advantages, and possibilities for SMEs' business development.

\section{Sampling process}

The process of selected published study is around 210. Of this electronics sample, 23 edocuments were not relevant because the majority of repeated studies and 139 publications did not convey cost Management in SMEs after considering titles, summary, abstract, and keywords (Almeida Parizotto et al., 2020). Maximum of them is not included in the particular areas. In that case, after the specific evaluation was evolved to leave out, only those are included samples was massively indicated cost management in SMEs and finance development areas. The study methods employed literature through empirical, field research, and analytical research. Table 6 shows that the details;

Table 6. Distribution of secondary samples

\begin{tabular}{|l|l|l|l|}
\hline & Empirical research & Analytical study & Field research \\
\hline Number of Publications & 38 & 21 & 8 \\
\hline Proportion & $56.72 \%$ & $31.34 \%$ & $11.94 \%$ \\
\hline
\end{tabular}

\section{ANALYSIS AND DISCUSSION}

The purpose of the study was to examine the relationship between strategic business planning procedures and financial contribution in SMEs in the 21st century. In addition, the conceptual framework analyzes and explains the cost management policy effective to improve SMEs and finance performance that gives a key contribution to knowledge about SMEs and leads to liked further study.

Based on a previous study, it appears that various organizations have realized these issues exist in the recent cost management system. When analyzing the major problems has revealed an important not much strength in the traditional cost management gateways. Furthermore, proper financial management is one of the most important aspects of a business's long-term sustainability and prosperity. The analyzing knowledge from previous research emphasizes that SMEs owners have to always be aware of the financial performance of their organization and the decisions they make as it affects the overall success of their business industry. Cost management is critical to the success of some more comprehensive activities, including client selection, marketing, and product division (Araujo \& da Costa, 2005). Each of these generates information related to the activity of the productive process. It is necessary to determine the profitability of the company and to determine the best competitive strategy for it. The Global corporate overviews in different countries and markets in search of achieving regional goals and maximizing. 


\section{The Role of Standard Costs in Cost Management}

Whenever SMEs set aims that companies want to succeed, these goals can be indicated standards. Periodically, businesses can measure original activities against these standards and emphasize the variety to profound how near businesses are to achieving the destination. Similarly, management considers goals such as set-up standards and comparing real costs with these aims to specify effective issues.

Any category of the business company has to identify what their costs are and capable to consider, and reason of spend to determine and control their profitability. The modern cost strategies always allocate costs based on quality. Because setting standards level is the strictest and crucial step in a well-functioning standard cost system, this segment emphasizes languish of the system. If the values are set correctly, are not updated to accomplish the recent state of operations, or do not match the amount of expenditure being allocated, it will not visualize current situations. The standard can be set incorrectly, for example, if the efficiency of operations is misjudged.

In today's competitive business era, enterprises often create a large variety of commodities, including short product life cycles. In such a situation, it is usually not easy to firstly adjust the spending standards to reflect the increased technological and market variables. As a result, quality relevance costs and variance reports stay an open query. In this stage, potentially product delivery becomes more significant than only producing a product that is manufactured according to the modern technologies employed as per the identifications of the consumers.

While the standard has proposed enrichment related to costs, for example, the skills and productivity and their underlying impact on the down line, time managing and waste reduction in operations, and the concept of costly opportunity in the minds of decision creators have largely created emergency issues related to its use. In general, potential quality engineering studies and the consequences of duration and speed studies are taken to narrate the number of materials, workforce, and extra services necessary to manufacture a product. The economic field conditions are also considered in describing standards because these situations affect the cost of materials and other performances that have to purchase through a manufacturing industry.

Table 2. Advantages of conducting standard costs

\begin{tabular}{|l|l|}
\hline Pillars & Definitions \\
\hline Develops cost control & $\begin{array}{l}\text { Organizations set Standards for every kind of expense and then } \\
\text { notable prospects or alternatives to things where things did not go } \\
\text { as planned. The variants examine a starting point for defining the } \\
\text { usefulness of directors in systematizing the amount of expenses } \\
\text { that are charged. }\end{array}$ \\
\hline $\begin{array}{l}\text { Planning and decision } \\
\text { making }\end{array}$ & $\begin{array}{l}\text { While management improves actual cost standards and achieves } \\
\text { in regulating production values, further real spending standards } \\
\text { must be closer. Hence, management may employ standard } \\
\text { expenditures to ready appropriate allocates and set costs for } \\
\text { mandate on employments. A quality cost system might be } \\
\text { remarkable for administrative management in terms of planning } \\
\text { and decision making. }\end{array}$ \\
\hline $\begin{array}{l}\text { Reasonable and easier } \\
\text { inventory measurements }\end{array}$ & $\begin{array}{l}\text { A standard costing system gives effective inventory evaluation } \\
\text { compared to an actual cost way. An actual costing system, costs }\end{array}$ \\
\hline
\end{tabular}




\begin{tabular}{|l|l|}
\hline & $\begin{array}{l}\text { for units for batches of similar products may vary } \\
\text { comprehensively. }\end{array}$ \\
\hline $\begin{array}{l}\text { Cost savings in record- } \\
\text { keeping }\end{array}$ & $\begin{array}{l}\text { In a standard cost procedure, an organization mentions that the } \\
\text { flow of costs between sales accounts and product content in a } \\
\text { consistent standard amount during the duration. Moreover, cost } \\
\text { system may necessary detailed records than real expenditure } \\
\text { system being the counting times. }\end{array}$ \\
\hline $\begin{array}{l}\text { Potential decrease in } \\
\text { production costs }\end{array}$ & $\begin{array}{l}\text { The main function of a standard cost system is to create activities } \\
\text { that can be economical. The use of standard costing can make } \\
\text { employees more aware of costs and find better ways to get their } \\
\text { work done. Only when workers become proactive in decreasing } \\
\text { costs can business ensure real success in controlling costs. }\end{array}$ \\
\hline
\end{tabular}

Table 3. Disadvantages of conducting standard costs

\begin{tabular}{|l|l|}
\hline Concept & Explanations \\
\hline $\begin{array}{l}\text { Controversial material } \\
\text { limits for variants }\end{array}$ & $\begin{array}{l}\text { Realizing the material limits of variants can be controversial. } \\
\text { Every business has a liability to decide what is the element or } \\
\text { unusual variant of management. Since materialization engages } \\
\text { particular judgment, there can be various issues or conflicts in } \\
\text { determining material boundaries. }\end{array}$ \\
\hline $\begin{array}{l}\text { Non-reporting of specific } \\
\text { variants }\end{array}$ & $\begin{array}{l}\text { Employees do not often record all exceptions or variations. If } \\
\text { administration merely investigates abnormal forms, employees } \\
\text { cannot report minus prospects to the allotment or may secretly } \\
\text { try to reduce these exceptions. Employees who able to in } \\
\text { concealment variants reduce the fruitfulness of the budget. }\end{array}$ \\
\hline Morale is low for few labors & $\begin{array}{l}\text { Administration by the exception way concentrate on } \\
\text { observable forms. Management always concerns on adverse } \\
\text { changes while avoiding applicable forms. Employees may } \\
\text { believe that inappropriate performance gets considerations } \\
\text { while ignoring best performance. Therefore, the morale of } \\
\text { these labors gets into trouble. }\end{array}$ \\
\hline
\end{tabular}

In short, directors of enterprises must take adequate care of them in using a standard cost system and must go out of boundaries to concentrate on the effective, instead of the negative and be aware of the potential unintentional results. Nevertheless, standard costs until available in a large number of manufacturing companies and several service organizations, although their conduct is transforming. For performance appraisal, standard cost variants next balances can be provided by an especially interesting improvement known as the scorecard.

Therefore, the advantages and disadvantages of these standard cost definitions are authenticity and precision. The noticeable of this is that they tend to be highly purposeful and determine the usefulness for all components.

Cost management is important for owners of SMEs as they discovered a lack of management skills, while the administration encouraged specific training programs (Ditkaew, 2018). Besides, Cost management is an effective strategic element for SME organizations as 
follows: (a) businesses are capable to negotiate prices to create workable profit; (b) it helps decline functional risks; (c) exact prediction of activity cost control and operation, and (d) appropriate cost estimation able business to under control stocked products administration significantly.

According to the literature study, the process associated with the availability of new products in the market is a relatively new field of strategic cost management research (Anderson, 2006). At the same time, traditional cost management business remains risky in any way, which can be inferred from the previous research. In addition, for financial and cost management Strategies in SMEs have been defined from different perspectives (Langfield-Smith, 1997). For example, a potential strategy is emphasized as a key component of the organization's future decisions, which takes meaning when it is applied through the organization's structures and procedures.

One of the segments that have obtained little concern in the field of strategy setting, especially in the study of SMEs, is financial decisions, although it is a determinant of business competition (Salazar et al., 2012).Financial analysis and planning, which represent the key factors that support organizational strategies, yet are practically non-existent in microenterprises, impose an obstacle on the kind of financial decisions that entrepreneurs can create in financial strategies demonstrates a way to gain and maintain business competitiveness and shows a position to list in the worldwide organization. Furthermore, different unfamiliar features of small business influence the cost of failure. The bankruptcy proportion among SMEs is gradually high, although the exact ratio is unknown (Boyle \& Desai, 1991). Because lack of business securities, incomplete management teams, limited alternative resources of capital, and discourage of risk can increase the likelihood (Ang, 1991). A key feature of a micro business is its limited capital sources and its focus on spending. In that case, effective consultants can be a strategy to reduce costs (Malhotra \& Temponi, 2010). There is a growing determination that the worldwide business currently is facing a set of new obstacles (e.g., globalization of competition, modern technologies, and growth) that require different ways to strategy (Kyobe, 2004). In the case of problems in attracting long-term money from market actors, such as banks and venture capital firms, small businesses face financial gaps (Winborg \& Landströmb, 2001).

Finally, the theoretical discussions of this study have incorporated the knowledge element of small business sustainability as a whole by suggesting a structural approach to integrate exact approaches as an essential component of their cost and finance management strategy for making business profit. Therefore, we acknowledge that this study did not consider the theoretical analysis identified as the cause of the difference in values of any particular individual or group. These theories need to be considered in order to achieve the goal of increasing SME openness towards more entrepreneurial values from a policy-making perspective.

\section{Obstacle and Challenges to growth of SMEs}

The first requirement for the expansion of a business is to create a conducive business environment. In this case, every country facing some key challenges and obstacles that are shown below the table. These are political stability, human resource development, proper power generation and supply, reduction of corruption, development in the information and technology sector, infrastructure development, etc. 
Table 4. The key challenges of SMEs in worldwide

\begin{tabular}{|l|l|l|l|l|l|l|l|l|}
\hline $\begin{array}{l}\text { Countries } \\
\text { and } \\
\text { Barriers }\end{array}$ & $\begin{array}{l}\text { Banks } \\
\text { Interest } \\
\text { Rate }\end{array}$ & $\begin{array}{l}\text { Political } \\
\text { Stability } \\
\text { (Percentil } \\
\text { e Rank) }\end{array}$ & $\begin{array}{l}\text { Human } \\
\text { Capital } \\
\text { Index } \\
\text { (Value) }\end{array}$ & $\begin{array}{l}\text { Electricity } \\
\text { and Power } \\
\text { Outage in } \\
\text { firm } \\
\text { (Value) }\end{array}$ & $\begin{array}{l}\text { World } \\
\text { Competit } \\
\text { iveness } \\
\text { Index } \\
\text { (Score) }\end{array}$ & $\begin{array}{l}\text { Corruption } \\
\text { Index } \\
\text { (Score) }\end{array}$ & $\begin{array}{l}\text { ICT } \\
\text { Development } \\
\text { Index } \\
\text { (Value) }\end{array}$ & $\begin{array}{l}\text { Quality } \\
\text { Infrastruct } \\
\text { ure Index } \\
\text { (Value) }\end{array}$ \\
\hline Bangladesh & $9 \%$ & 16.04 & 0.46 & 64.5 & 3.9 & 26 & 2.30 & 2.91 \\
\hline India & $8.5 \%$ & 16.98 & 0.49 & 13.8 & 4.6 & 40 & 2.50 & 4.56 \\
\hline Malaysia & $7 \%$ & 50.94 & 0.61 & 0.1 & 5.2 & 51 & 5.60 & 5.31 \\
\hline Indonesia & $12.57 \%$ & 28.30 & 0.54 & 0.5 & 4.7 & 37 & 3.60 & 4.13 \\
\hline Kazakhstan & $12.66 \%$ & 39.15 & 0.63 & 0.5 & 4.3 & 38 & 6.40 & 3.19 \\
\hline Tajikistan & $22 \%$ & 27.36 & 0.50 & 1.3 & 4.1 & 25 & - & 4.17 \\
\hline China & $4.86 \%$ & 37.74 & 0.65 & 0.1 & 5.0 & 42 & 4.80 & 4.53 \\
\hline Korea & $3.82 \%$ & 62.74 & 0.80 & - & 5.1 & 61 & 8.80 & 5.65 \\
\hline Egypt & $5 \%$ & 11.32 & 0.49 & 0.8 & 3.9 & 33 & 4.30 & 4.02 \\
\hline $\begin{array}{l}\text { South } \\
\text { Africa }\end{array}$ & $5.75 \%$ & 40.57 & 0.43 & 7.7 & 4.3 & 44 & 4.70 & 4.05 \\
\hline Nigeria & $9 \%$ & 4.72 & 0.36 & 32.8 & 3.3 & 25 & 2.50 & 2.32 \\
\hline Tanzania & $20 \%$ & 33.02 & 0.39 & 8.9 & 3.7 & 38 & 1.50 & 3.59 \\
\hline Canada & $5.3 \%$ & 90.09 & 0.80 & - & 5.3 & 77 & 7.60 & 5.21 \\
\hline $\begin{array}{l}\text { United } \\
\text { States }\end{array}$ & $5.26 \%$ & 46.23 & 0.70 & - & 5.9 & 67 & 8.10 & 5.85 \\
\hline Australia & $4.18 \%$ & 73.11 & 0.77 & - & 5.2 & 77 & 8.20 & 4.70 \\
\hline $\begin{array}{l}\text { New } \\
\text { Zealand }\end{array}$ & $9 \%$ & 97.64 & 0.78 & - & 5.4 & 88 & 8.10 & 4.76 \\
\hline & & & & & & & \\
\hline
\end{tabular}

Source: Bangladesh Bank, ADB, World Bank, and OECD

One of the initial necessities for the progress and expansion of SMEs is to get loans in a time with a low-interest rate. Reviewing the data, it is seen that the barriers to getting short-term and long-term loans in upper income and middle-income countries are less than those in developing countries. Also, due to the reluctance of private banks to be involved in the SMEs sector, SMEs rely on NGOs and other parties. In addition, the growth of the SMEs sector in developing countries is being hampered by high-interest rates on bank loans. In Indonesia, the bank's interest rate on SMEs is 12.57\%, in Kazakhstan 12.66\%, in Bangladesh 9\% (5\% with bank rate), (Bangladesh Bank, 2010), and in India average of 8.5\% (Central Bank of India, 2020). Whereas the lowest interest rate in Australia has an average interest rate of $4.18 \%$, Canada has an average interest rate of 5.3\%, Korea republic has an interest rate of $3.82 \%$, Malaysia has an interest rate of 7\%, New Zealand has an interest rate of 9\%, China has an interest rate of $4.86 \%$ and the United States has an interest rate of 5.26\% (OECD, 2021). While the highest SMEs interest rate in Tanzania average 20\% (JICA, 2017) and in Tajikistan 22\% (OECD, 2015). As the interest rate is high on the loan, the institution has to pay extra dues (Olawale \& Garwe, 2010). In this, the cost of the organization be excessively more than the profits indicated by Ferrari el al. (2018)

Political stability refers to how secure and volatile a country's business environment is by a country's political parties. These instabilities include strikes, riots, destruction of domestic and foreign resources, deterioration of the law-and-order situation, increase in terrorism, loss of 
human life and property by violence, etc. A destroyed business environment creates a big obstacle for the expansion of SMEs and foreign industries of the country. As a result of political instability, disrupt the movement of vehicles, reduce purchases and sales, and interrupt the flow supply chain of raw materials, hampered production, and so on. Consequently, SMEs face financial losses for the production, distributions and management costs to be high (Rehman et al., 2019). The growth of the country, which is ahead in the index of political stability, is much higher. In this case, the countries are in a good position of political stability index with Percentile Rank are New Zealand 97.64, Canada 90.09, Australia 73.11, Korea Republic 62.74, Malaysia 50.94, United States 46.23, South Africa 40.57. Countries that are in the middle and bottom line of political stability are Kazakhstan 39.15, China PR 37.74. Tanzania 33.02, Indonesia 28.30, Tajikistan 27.36, India 16.98, Bangladesh 16.04, Egypt 11.32, Nigeria 4.72(World Bank, 2021).

Human capital or human resources state to employees have the knowledge and skills on productivity, talents, and other invisible qualities or qualifications to succeed in the organization properly. A skilled and trained worker is equally adept at solving any problem of the organization at any crucial time. They also become proficient in how to produce more in less time at a lower cost. As a result, the depreciation of the organization is reduced as well as the operating cost (Mahmood, 2008). According to The World Bank (2020) report the high-income and upper-middle-income countries capable of creating skilled human resources with values are the Korea Republic 0.80, Australia 0.77, Canada 0.80, New Zealand 0.78, US 0.70, China 0.65, Kazakhstan 0.63, Malaysia 0.61, Indonesia 0.54, South Africa 0.43. The lower middle income and low-income countries are Tajikistan 0.50, Egypt 0.49, India 0.49, Bangladesh 0.46, Tanzania 0.39 , and Nigeria 0.36 .

Incessant power supply speeds up the production of any organization. As a result, the organization is able to achieve its set goals. Power outages are deficit in power generation, inequality in power distribution, load shedding, etc. The countries with the least power outages in firms with values are New Zealand, The United States, Australia, Korea Republic, and Canada. The countries that have not been able to deliver proper electricity in industries and firms, and deficits in power distribution are Bangladesh, India, Tanzania, Nigeria reported by World Bank (2020).

Competitiveness is to prioritize the customer's demand for the survival of the same products of many companies in the market. It also involves maintaining product quality, color and design skills, fair pricing, entry into domestic and international markets, export market range, and so on. Competitiveness helps a company to reach its goals, but also plays a role in bringing out productivity from employees. In this case, multinational companies give to customers various offers, discounts, and temptations to capture the whole market. As a result, it is difficult for newly established SMEs to survive in the competition. United States, New Zealand, Australia, Canada, and China are ahead in this regard. Bangladesh, Egypt, Tanzania, and Nigeria are lag behind (World Economic Forum, 2018).

Excessive corruption and bribery hamper the progress of a country's economy. Corruption in administrative functions such as environmental pollution control, food adulteration verification, industry, and industrial product quality authentication, firefighting system confirmation, technical and education quality substantiation, transportation quality verification, water, and natural resource management and burglary verification, environmental inspection by company, etc. The prescribed growth of the country will not be achieved without these proper supervisions. If the administration becomes corrupt, the production and management costs become high for the extreme price of gas, electricity bills, and also extra charges by the 
administrators (Aristovnik \& Obadić, 2015). As a result, SMEs, and industrial factories don't gain much momentum. The inclusion of SMEs in the growth of corrupted countries is much lower. Whereas, the contribution of SMEs to the GDP of less corrupted countries is much higher. High corrupted countries with scores are Tajikistan, Nigeria, Bangladesh, Egypt, Indonesia, Kazakhstan, and Tanzania. Transparency International (2020) reported the least corrupted countries with scores are New Zealand, Australia, Canada, United States, Malaysia, South Africa, China, and India.

It is impossible to survive in the competitive world market without modern and latest information technology. SMEs are required to increase the use of modern information technology to high production in less time at a lower cost. In addition, expansion of technical education, increase in the use of advanced technology, increase in opportunities to import technology, and reduction in the cost of import technology have resulted in capacity building of SMEs expansion. The significant progress of those countries in the field of information and technology, their SMEs establishments have expanded rapidly, and their contribution to GDP is quite good, which is more than the undersized countries in the field of information technology. The foremost countries in the ICT development index are the Republic of Korea 8.80, Australia 8.20, the United States 8.10, New Zealand 8.10, and Canada 7.60. Whereas, the least countries are Bangladesh 2.30, India 2.50, Malaysia 5.60, Indonesia 3.60, Kazakhstan 6.40, China 4.80, Egypt 4.30, South Africa 4.70, Nigeria 2.50, Tanzania 1.50 individually (ITU, 2021).

Infrastructure development means sustainable development of communication systems including air, water, rail, construction of appropriate bridges and highways, development in power and energy sector, ensuring proper utilization of water and natural resources, development in information technology, science, research sector, waste management, and environment, ensuring proper security, human resource development. Also, social infrastructure includes development in the education and health sectors, ensuring emergency services. The government services include ensuring consumer protection laws, taking appropriate steps to stop adulterated products, and acquiring disaster management capabilities. The inclusion of SMEs in the GDP of developed countries in the infrastructure sector is higher than that of weaker countries. The leading countries in the Quality Infrastructure Development Index values are the United States 5.85, Korea Republic 5.65, Malaysia 5.31, Canada 5.21, New Zealand 4.76, and Australia 4.70. Infrastructure development indicators of middle income, low income, and developing countries are, Bangladesh 2.91, India 4.56, Indonesia 4.13, Kazakhstan 3.19, China 4.53, Egypt 4.02, South Africa 4.05, Nigeria 2.32, Tanzania 3.59 respectively (The World Bank, 2017).

\section{RECOMMENDATIONS AND CONCLUSION}

The purpose of the study is to provide recommendations regarding improving the financial management of the SMEs and develop the applicable strategy, it should include technological innovations that support financial accounting systems to keep a record of financial transactions of SMEs owners, properly accumulate financial data with internal and external stakeholders, and keep concentration with all kinds of new research strategies which useful practice in cost management.

In addition, the small and medium enterprise is the main contributor to keeping the growth of a country's economy, and the growth of the SMEs sector has created employment and reduced joblessness, and also accelerated the GDP. Moreover, the improvement in the SME sector has reduced the country's import dependence. Accordingly, the price of the product remains within the purchasing power of the people. Development of the SME sector means 
socio-economic development, increase in per capita income, and increase in production. However, the development of the SME sector requires proper supervision, and infrastructure development, corruption control. Consequently, the cost management of the SME sector will decrease with the procurement of raw materials and transportation costs. Accordingly-

Firstly, investment is the first required element to start a business, and it is the lifeblood of any business. It is necessary to ensure the financial institutions to availability of loans at the low-interest rate with the easiest policy.

Secondly, it is impossible to develop a business without the skills of amateurish workers. The purpose of the skilled labor force government should establish training institutions, expansion of technical education, provision of training in the private and public sectors.

Thirdly, the government has to create a suitable business-friendly environment. Whereas, political stability, well-organized business policies, a smooth communication system for the transportation of goods, a terror-free environment, and administrative effort will remain corruption-free.

Fourthly, to create opportunities for the export of duty-free goods and to take initiative to build business relations with giant domestic and foreign companies. By establishing this relationship, domestic companies will be able to enter the international market and focus on improving product quality with the competition. Furthermore, it will be able to emerge as a strong export sector in the world market.

The role of a fruitful strategy is to attain the workable policies right and implement them, which provides growing knowledge with evidence. That proper gateway is generally concentrated on improving in an impressive and conducive situation that able to large or small businesses, to thrive and allow any business to succeed.

The few previous research sampling processes and observation methods employed in this study impose certain limitations, as well as mentions measurable perspectives for further study. In particular, the contribution of research about the dynamically of the financial crisis is hard to get a definite concept of a thorough review of literature work alone without statistical analysis.

The major implication of this current research to the knowledge includes the appreciation of the conduct of special models during the business recession in the 21 st century. The article emphasizes strategic cost management, global challenges of SMEs business, and performance level as well as points out the links between the dimensions of business financial structural cost management. The previous research has indicated concise evidence examining the establishment and impact of business management financial systems and analysis. This study highlights that implementation allows cost management performance analysis to help provide empirically structured cost management and definition of finance structure. It plays a role in creating perfection of knowledge in managing strategic expenditure.

\author{
AUTHOR CONTRIBUTIONS \\ Conceptualization: Zahirul Alam Kajal, MukutSikder \\ Data curation: Zahirul Alam Kajal, Ashamoni \\ Formal analysis: Zahirul Alam Kajal, Ashamoni \\ Software: Zahirul Alam Kajal \\ Validation: Zahirul Alam Kajal, Ashamoni \\ Writing - Original Draft: Zahirul Alam Kajal, MukutSikder
}


Writing - Review \& Editing: Zahirul Alam Kajal,MukutSikder,ParussPanhwar, Ashamoni

\section{CONFLICT OF INTEREST STATEMENT}

The authors declare no conflict of interest.

\section{REFERENCES}

ADB. (2019). Leveraging sme finance through value chains in tajikistan.

ADB. (2014). Sector assessment (summary): finance (small and medium-sized enterprise finance and leasing)a.

ADB. (2016). SMEs in Developing Asia New Approaches to Overcoming Market Failures.

ADB. (2017). Thematic Evaluation: ADB Support for SMEs.

Akbar, S., Ali, M., \& Dalziel, M. (2011). The journey to develop educated entrepreneurs: prospects and problems of Afghan businessmen. Education \& Training, 53 (5), 433 447, http://dx.doi.org/10.1108/00400911111147730.

Almeida Parizotto, L. d., Tonso, A., \& Carvalho, M. M. (2020). The challenges of project management in small and medium-sized enterprises: a literature review based on bibliometric software and content analysis. Gestão \& Produção, 27 (2), 1-23, https://doi.org/10.1590/0104-530X3768-20.

Anderson, S. W. (2006). Managing Costs and Cost Structure throughout the Value Chain: Research on Strategic Cost Management. Handbook of Management Accounting Research, 2, 481-506.

Ang, J. S. (1991). Small Business Uniqueness and the Theory of Financial Management. Journal of Small Business Finance, 1 (1), 1-13.

Araujo, J. A., \& da Costa, R. P. (2005). Operations strategy and cost management. Journal of Information Systems and Technology Management, 2 (3), 291-303.

Aristovnik, A., \& Obadić, A. (2015). The impact and efficiency of public administration excellence on fostering SMEs in EU countries. Amfiteatru Economic Journal, 17 (39), 761-774.

Asian Development Bank. (2020). Asia small and medium-sized enterprise monitor 2020.

Asian Development Bank. (2016). SMEs in Developing Asia New Approaches to Overcoming Market Failures.

Bangladesh Bank. (2010). Small and Medium Enterprise (SME) Credit Policies \& Programmes. SME \& Special Programmes Department.

Bangladesh Bank. (2010). Small and Medium Enterprise (SME) Credit Policies \& Programmes. Bank, W. (2020). Power outages in firms in a typical month.

Boohene, R., Sheridan, A., \& Kotey, B. (2008). Gender, personal values, strategies and small business performance: A Ghanaian case study. Equal Opportunities International, 27 (3), 237-257. https://doi.org/10.1108/02610150810860075.

Boyle, R. D., \& Desai, H. B. (1991). Turnaround Strategies for Small Firms. Journal of Small Business Management, 29 (3), 33.

Central Bank of India. (2020). Interest Rate on Loan. 
Central bank of nigeria. (2010). N200 billion small and medium enterprises (sme) credit guarantee scheme (smecgs).

Ditkaew, K. (2018). The Effects of Cost Management Quality on the Effectiveness of Internal Control and Reliable Decision-Making: Evidence from Thai Industrial Firms. Advances in Social Science, Education and Humanities Research.211, pp. 60-69. Atlantis Press.

Djauhari sitorus. (2017). Improving access to finance for SMEs in Tanzania: Learning from Malaysia's experience. The World Bank.

Elliott, G. (2004, 11 8). The seven principles of effective cost management. Retrieved 117 , 2021, from Natural Products Insider: https://www.naturalproductsinsider.com/businessresources/seven-principles-effective-cost-management

FE Ombudsman. (2020). Small Business Counts. Australian Government.

Ferrari, A., Masetti, O., \& Ren, J. (2018). Interest Rate Caps: The Theory and the Practice. Policy Research Working Paper.

Fuertes, G., Alfaro, M., Vargas, M., Gutierrez, S., Ternero, R., \& Sabattin, J. (2020). Conceptual Framework for the Strategic Management: A Literature ReviewDescriptive. Journal of Engineering , 1-21, https://doi.org/10.1155/2020/6253013.

Government of Canada. (2020). Key Small Business Statistics - 2020.

IFC. (2018). The unseen sector a report on the msme opportunity in south africa.

ITU. (2021). World Telecommunication/ICT Indicators Database.

JICA. (2017). Data Collection Survey on Small and Medium Enterprise Finance in the United Republic of Tanzania.

Jindrichovska, I. (2013). Financial Management in SMEs. European Research Studies , 80-96.

Kaličanin, D., \& Todorović, M. (2014). Interactions between business and financial strategies in serbian companies. Economic Annals , 55-74, https://doi.org/10.2298/EKA1403055K.

Karadag, H. (2015). Financial Management Challenges In Small and Medium-Sized Enterprises: A Strategic Management Approach. Emerging Markets Journal, 5 (1), 2640, https://doi.org/10.5195/emaj.2015.67.

Kenyon, G. N., \& Meixell, M. J. (2011). Success factors and cost management strategies for logistics outsourcing. Journal of Management and Marketing Research .

Kumar, A., \& Nagpal, S. (2011). Strategic cost management - suggested framework for 21st Century. Journal of Business and Retail Management Research, 5 (2), 118-130.

Kyobe, M. E. (2004). Investigating the Strategic Utilization of IT Resources in the Small and Medium-Sized Firms of the Eastern Free State Province. International Small Business Journal, 22 (2), 131-158, https://doi.org/10.1177\%2F0266242604041311.

Langfield-smith, k. (1997). Management control systems and strategy: a critical review. Accounting, Organizations and Societ, 22 (2), 207-232, https://doi.org/10.1016/S03613682(95)00040-2.

Li, Y. (2017). The Research of the Financial Strategy of SY Education Consulting Group. Business and Management Research, 6 (3), 17-21, https://doi.org/10.5430/bmr.v6n3p17. 
Mahmood, M. (2008). Labour productivity and employment in Australian manufacturing SMEs. International Entrepreneurship and Management Journal , 51-62.

Malayeri, a. D., \& mastorakis, n. E. (2012). Innovative Management in Cost Management Strategies . Advances in Finance and Accounting , 360-365.

Malhotra, R., \& Temponi, C. (2010). Critical decisions for ERP integration: Small business issues. International Journal of Information Management, 30 (1), 28-37, https://doi.org/10.1016/j.ijinfomgt.2009.03.001.

Michael, O. B. (2013). Strategic Cost Management as a recession survival tool in the Nigerian Manufacturing and Financial Service Industries. Research Journal of Finance and Accounting, 4 (11), 71-81.

Ministry of Business. (2018). New Zealand's Support for Small Business. New Zealand Government.

OECD. (2010). Business climate development strategy.

OECD. (2015). Enhancing access to finance for SME development in Tajikistan.

OECD. (2015). Enhancing access to finance for SME development in Tajikistan.

OECD. (2021). Financing SMEs and Entrepreneurs: An OECD Scoreboard.

Olawale, F., \& Garwe, D. (2010). Obstacles to the growth of new SMEs in South Africa: A principal component analysis approach. African Journal of Business Management , 729738.

PWC. (2020). PwC's MSME Survey 2020.

Rehman, N. U., Çela, A., Morina, F., \& Gura, K. S. (2019). Barriers to growth of SMEs in Western Balkan countries. Journal of Management Development , 2-24.

Rocha de Araujo, J. A., \& Pacheco da Costa, R. (2005). Operations strategy and cost management. Journal of Information Systems and Technology Management, 2 (3), 291-303.

Salazar, A. L., Soto, R. C., \& Mosqueda, R. E. (2012). The impact of financial decisions and strategy on small business competitiveness. Global journal of business research, 6 (2), 93-103.

Sandada, M., \& Dubihlela, J. (2017). Impact of Strategic Planning on Small and Medium-Sized Enterprises' (SMEs)Performance: The Role of Employee Participation,Implementation Incentives and Evaluation and Control. Journal of Economics, 5 (1), 45-55, http://dx.doi.org/10.1080/09765239.2014.11884983.

Savić, B., Vasiljević, Z., \& Đorđević, D. (2014). Strategic cost management as instrument for improving competitiveness of agribusiness complex. Economics of Agriculture , 10051020.

Sulanjaku, M., \& Shingjergji, A. (2015). Strategic cost management accounting instruments and their usage in albanian companies. European Journal of Business, Economics and Accountancy, 3 (5), 44-50.

The World Bank. (2017). Quality of overall infrastructure.

The World Bank. (2020). The Human Capital Index 2020 Update. 
TRADE, M. O. (2003). Small and medium enterprise development policy 2003. Tanzania.

Transparency International. (2020). Corruption perceptions index 2020.

Umadia Sr, K., \& Kasztelnik, K. (2020). The Financial Innovative Business Strategies of Small to Medium Scale Enterprises in Developing Country and Influence for the Global Economy Performance. SocioEconomic Challenges, 4 (3), 20-32, https://doi.org/10.21272/sec.4(3).20-32.2020.

United States International Trade Commission. (2010). Small and Medium-Sized Enterprises: Overview of Participation in U.S. Exports.

Voronkova, o. V., firova, i. P., kurochkina, a. A., \& bikezina, t. V. (2019). Management features of small and medium-sized business enterprises. Revista ESPACIOS, 40 (34).

Wall, B., Neumark, D., \& Zhang, J. (2011). Do small businesses create more jobs? New evidence for the united states from the national establishment time series. The Review of Economics and Statistics, 93 (1), 16-29, https://doi.org/10.1162/REST_a_00060.

Wang, Y. (2019). Strategic Cost Management-A Review of Research Status at Home and Abroad. Modern Economy, 10, 513-522, https://doi.org/10.4236/me.2019.102035.

Winborg, j., \& Landströmb, H. (2001). Financial bootstrapping in small businesses: Examining small business managers' resource acquisition behaviors. Journal of Business Venturing, 16 (3), 235-254, https://doi.org/10.1016/S0883-9026(99)00055-5.

World Bank. (2021). Worldwide Governance Indicators.

World Economic Forum. (2018). Global Competitiveness Index.

World Bank. (2021). Small and Medium Enterprises (SMEs) Finance.

\section{Copyrights}

Copyright for this article is retained by the author(s), with first publication rights granted to the journal. This is an open-access article distributed under the terms and conditions of the Creative Commons Attribution license (https://creativecommons.org/licenses/by/4.0). 